(C) 2016

Скрипніченко С. В., кандидат сільськогосподарських наук,

Коцюба I. Г., кандидат технічних наук

Житомирський державний технологічний університет

\title{
ТРАНСФОРМАЦІЯ ТОРФОВИЩ У ПРОЦЕСІ ОСУШЕННЯ ТА ДОВГОТРИВАЛОГО СІЛЬСЬКОГОСПОДАРСЬКОГО ВИКОРИСТАННЯ
}

\section{Рецензент - кандидат сільськогосподарських наук І. В. Давидова}

Викладено результати багаторічних досліджень впливу осушення та освоєння на трунтотворні процеси торфових трунтів $і$ запропоновано екологічно безпечні заходи їх раціонального та ефективного використання. Визначено, щзо темпи руйнування лляного полотна найінтенсивніші в просапній сівозміні. Осушення та довготривале освоєння торфових трунтів відбуваються з істотними змінами їх властивостей: збільшується щільність трунту $і$ зольність, а повна вологоємкість зменшується.

Ключові слова: осушення, сівозміна, торфові трунти, родючість, трунтотворні прочеси.

Постановка проблеми. Осушувальна меліорація є потужним чинником, який докорінно змінюе грунтотворні процеси. У багатьох дослідженнях велика увага приділяється проблемі зменшення органічної речовини торфу («спрацюванню») у випадку інтенсивного їх використання. Одні вчені у цьому терміні розуміють об'ємне зменшення торфу у тримірному вимірюванні, а інші - зменшення потужності покладів торфу [2, 3]. Водночас зменшення маси торфу розглядається без урахування якісних змін органіки та фізико-хімічних перетворень. Відомо, що мінералізація супроводжується процесами гуміфікації, які проходять одночасно. В одних умовах переважають процеси розкладу, в інших синтезу [1]. Якщо до осушення в грунті переважала пухка органогенна маса 3 рослин торфоутворювачів та низьким вмістом вуглецю та азоту, то в процесі гуміфікації утворюються складні високомолекулярні сполуки з великим вмістом органогенних елементів.

Аналіз останніх досліджень i публікацій, у яких започатковано розв'язання проблеми. Проблемі трансформації торфових грунтів під впливом сільськогосподарського використання присвячено чимало наукових праць. Однак для Західного Полісся України [1] кількість даних про закономірності та напрямки протікання грунтових процесів, зміни властивостей і режимів під впливом осушення та тривалого освоєння $\epsilon$ недостатньою [3]. Тому, незважаючи на знач- ний наявний практичний досвід використання органогенних грунтів, актуальним $\epsilon$ перегляд деяких положень і технологічних аспектів, удосконалення їх на сучасному етапі для розробки науково обгрунтованого комплексу заходів раціонального використання торфовищ.

Мета дослідження - виявити особливості трансформації осушуваних торфових грунтів у разі довготривалого сільськогосподарського використання та розробити і впровадити екологічно безпечні заходи по їх збереженню.

Завдання дослідження - встановити закономірності і напрямки грунтових процесів для обгрунтування і впровадження комплексу заходів по збереженню i раціональному використанню торфовищ.

Об'єкт і методика досліджень. Об'єктом досліджень $є$ процес трансформації торфових грунтів під впливом осушення і сільськогосподарського використання та продуктивність агрофітоценозів у сівозмінах різних видових груп. Методика проведення досліджень загальноприйнята.

Результати досліджень. Результати багаторічних наукових досліджень, проведених науковцями Сарненської дослідної станції (Рівненська обл.) в умовах Західного Полісся, дали змогу виявити та простежити загальні напрямки і тенденції грунтоутворюючих процесів під впливом осушення та сільськогосподарського використання. На основі аналізу архівного матеріалу із залученням результатів сучасних досліджень встановлено, що інтенсивний період використання торфового масиву сприяе інтенсивним темпам мінералізації органічної речовини та частковій іiі гуміфікації. Якщо підвищення ступеня мінералізації торфу з точки зору грунтоутворення - явище позитивне, то інтенсивна їх мінералізація - явище негативне, оскільки супроводжується зменшенням запасів органічної речовини, посиленням гідрофобності, утворенням надлишкового азоту тощо. Обробіток грунту, застосування засобів хімізації вирощуваних культур, функціонування окремих фізіологічних груп мікроорганізмів обумовлюють специфіку динаміки грунтових ре- 


\section{СІЛЬСЬКЕ ГОСПОДАРСТВО. РОСЛИННИЦТВО}

жимів, направлених на посилення окислювальних процесів, а разом 3 тим на інтенсивне руйнування самої органічної речовини торфу. Відповідну сукупність меліоративних та агротехнічних заходів можна вважати комплексом чинників оптимізації властивостей, його режимів і процесів. Під впливом тривалого осушення та інтенсивного використання докорінно змінюються хімічні та водно-фізичні властивості торфового грунту. Так, щільність 0-30 шару грунту майже за 90 років використання збільшилась від

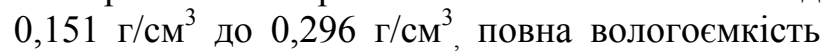
зменшилась відповідно від 546 до $295 \%$, зольність грунту зросла від 14 до 28 \%. Водночас довготривале освоєння не відображається на кількості загального азоту і калію в торфовому грунті. Мінералізація торфу також не сприяє закріпленню колоїдним комплексом калію в необмінну форму, а призводить до його вивільнення і переведення в рухомі, доступні для рослин сполуки. Так, відсоток доступної форми цього елементу в просапній сівозміні досягав 70, тоді як на монокультурі багаторічних трав лише 28 \%. Зростання на $30 \%$ вмісту фосфору за рахунок інтенсивного сільськогосподарського використання обумовлено: частковим його закріпленням із добрив та за рахунок значної наявності фосфору у вівіанітових прошарках, які мали місце в грунтовому профілі. Окрім цього, простежується чітка тенденція зниження приросту фосфору по мірі переважання в сівозміні багаторічних трав. Запобігти повній мінералізації торфу за його сільськогосподарського використання неможливо, проте цей процес можна регулювати. Важливим фактором, що зменшує його інтенсивність є оптимізація водно-повітряного режиму, тобто вибір норми осушення. Менш інтенсивне спрацювання торфу і винос пиловидних частинок вітром від- бувається під культурами вузькорядної сівби та під багаторічними травами. Наявність архівного матеріалу, доповненого результатами останніх досліджень дали змогу провести аналіз трансформації торфового грунту. Аналізуючи використання грунту під польову (56 \% - просапні, 44 \% - зернові) і кормову сівозміни (11\% - просапні, $33 \%$ - зернові, $56 \%$ - багаторічні трави) слід відмітити, що за перші 20 років освоєння в польовій сівозміні втрачалось до 25 т/га органічної речовини торфу. За наступні 60 років ці показники зменшувались до $60 \%$. Втрата органіки в кормовій сівозміні в 2-3 рази менша, ніж у польовій сівозміні. Введення в структуру посівних площ до $100 \%$ просапних культур призводить до значного щорічного зменшення запасів органічної речовини торфу (20-22 т/га).

На процеси гуміфікації і мінералізації органічних сполук впливають також температура і вологість. Для розвитку мікробіологічних процесів у грунтах оптимальними $є$ температура біля $30{ }^{\circ} \mathrm{C}$ і вологість близько 60-80 \% від повної вологоємкості. Надлишок чи недостача тепла і вологи призводить до гальмування процесів біологічної мінералізації і гуміфікації. Так, екстремальні умови сповільнювали швидкість розкладу лляної тканини (метод аплікацій), яку щорічно закладали на глибину 0-30 см на 60 днів для оцінки інтенсивності мінералізації органічної речовини торфу під впливом різних кліматичних умов і заходів сільськогосподарського використання. Результати багаторічних спостережень свідчать, що темпи руйнування лляного полотна найінтенсивніші в сівозміні просапній - 60,8 \%, восьмирічний лучний період у 4 рази гальмує процес мінералізації органічної речовини торфу $-15,8 \%$ (див. рис.).

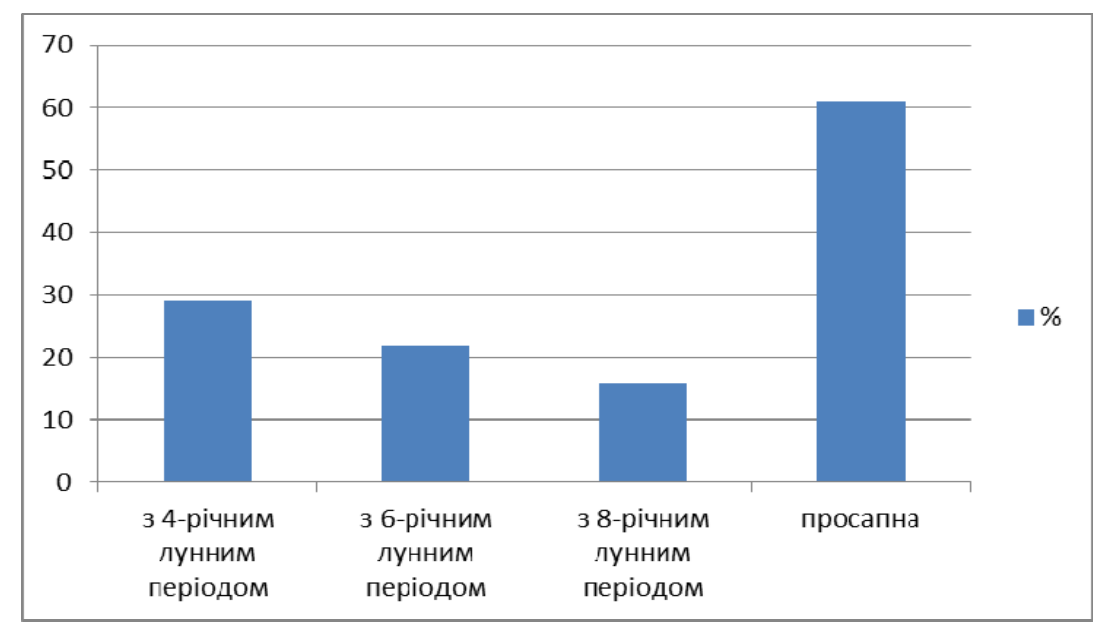

Рис. Розклад лляного полотна в сівозмінах різної інтенсивності (в середньому за 5 років у 0-30 см шарі трунту) 


\section{СІЛЬСЬКЕ ГОСПОДАРСТВО. РОСЛИННИЦТВО}

Під час використання методу аплікацій потрібно мати на увазі, що вони дають результати про наслідки руйнування тільки клітковини в грунті, а в складі органічної речовини переважають більш стійкіші компоненти: гумусові речовини, лігнін, негідролізований залишок тощо, які руйнуються значно повільніше. У торфовому грунті поряд з біохімічним розпадом органічних речовин на більш мілкі мономерні структури, відбувається новоутворення, синтез високомолекулярних сполук специфічної природи, таких як гумусові кислоти. Головною хімічною ознакою грунтотворного процесу торфових грунтів $\epsilon$ накопичення органічних кислот, як нерозчинних у воді, так і розчинних. Лігнін хоча і $є$ стійкою речовиною, однак в умовах грунтового середовища він руйнується, утворюючи ряд фенольних продуктів.

Сільськогосподарські культури по різному впливають на мінералізацію торфового грунту за рахунок їх кореневих i післяжнивних решток. Дослідження показали, що найбільшу їх кількість залишають багаторічні трави і кукурудза на силос - відповідно 57,0 і 42,3 ц/га, найменшу кормові буряки $-3,1$ ц/га. Зернові культури (ячмінь, озиме жито) займають проміжне місце відповідно 25,0 і 30,1 ц/га.

Таким чином, багаторічні трави $є$ важливим

\section{БІБЛІОГРАФІЯ}

1. Бамбалов Н. Н. Баланс органического вещества торфяных почв и методы его изучения / Н. Н. Бамбалов. - Минск : Наука и техника, 1984. - $81 \mathrm{c}$.

2. Прістер Б. С. Підвищення родючості і охорона осушених земель гумідної зони : довідник / Б. С. Прістер, Р. С. Трускавецький, М. М. Мос- фактором регулювання родючості торфових грунтів і вони повинні займати провідне місце в структурі посівних площ. Тривалість користування багаторічними травами залежить від товщини шару торфу, ступеня його осушення грунту та його розкладу. За результатами наших досліджень найвищий рівень продуктивності у багаторічних трав 2-3-х років використання (89 i 96 ц/га сіна). Починаючи з 4-го року використання, їх продуктивність знижувалась до 70,5 ц/га, а урожайність трав 7-8 року була найнижчою і становила $47,2-38,5$ ц/га.

Висновок. Під впливом осушення та довготривалого освоєння торфових грунтів відбуваються істотні зміни їх властивостей: збільшується щільність грунту і зольність, а повна вологоємкість зменшується.

Слід зазначити, що темпи мінералізації органічної речовини торфу в основному залежать від характеру сільськогосподарського використання. Найбільша середньорічна втрата органіки в просапній сівозміні (20-22 т/га). Лучний довготривалий період використання гальмує цей процес у 3-4 рази. У зв'язку з цим необхідно дотримуватись заощадливої системи землеробства, яка забезпечить: економію та збереження торфових грунтів; комплексну оптимізацію функціонування головних компонентів родючості грунту.

товий. - К. : Урожай, 1993. - С. 74-76.

3. Писаренко В. М. Агроекологія : навчальний посібник / Писаренко В. М., Писаренко П. В., Писаренко В. В. - Полтава, 2008. - С. 83-97

4. Сільськогосподарське використання осушених земель гумідної зони : рекомендації. - К. : Аграрна наука, 2000. - С. 3-28. 